\title{
Salmon fry predation by seabirds near an Alaskan hatchery
}

\author{
D. Scheel*, K. R. Hough \\ Prince William Sound Science Center, Box 705, Cordova, Alaska 99574, USA
}

\begin{abstract}
We estimated the mortality of hatchery-raised pink Oncorhynchus gorbuscha and chum O. keta salmon fry from seabird predation near a salmon hatchery in Lake Bay, Prince William Sound, Alaska, USA. Field counts of seabirds and observations of feeding rates for plunge-diving seabirds were obtained durng salmon fry releases between April and June 1995. Several hundred birds of 7 piscivorous species aggregated in front of the hatchery. Consumption rates were determined from focalanimal sampling and energetic models. For most species, per capita consumption rates based on behavioral data were lower than those calculated from energetic considerations. From energetic models and fry movement rates, we estimated that 2.7 to 5.9 million juvenile salmon 1.1 to $2.4 \%$ of released fry) were consumed during the study period. Differences between the energetics models accounted for $64 \%$ of this range; assumptions about fry movement rates accounted for the remainder. Gulls recorded during aerial surveys throughout Prince William Sound were significantly associated with spawning herring and hatchery sites, but not with miles of coast with herring spawn present. The correlation of bird aggregations with the presence of these small fish indicates that concentrations of prey fish have an important influence on the distribution of birds at sea during this time of the year. Bird numbers in both boat counts and aerial surveys declined from early May to early June. Taken together, these results indicate that salmon fry just entering the marine environment were not especially susceptible to avian predation. Their vulnerability to predation was apparently buffered by the presence of other attractive food patches within seabird foraging range early in our study period, and by declines in the numbers of seabirds foraging along the shoreline later in the study.
\end{abstract}

KEY WORDS: Seabirds Salmon Salmon hatcheries Energetics Predation Alaska

\section{INTRODUCTION}

Estimated rates of predation form the basic data for many areas of ecology, such as our understanding of habitat selection (e.g. Hugie \& Dill 1994, Rochette \& Himmelman 1996), predator and prey population cycles (e.g. Volterra 1926, Korpimaki \& Krebs 1996), or species coexistence (Vincent et al. 1996). The same estimates are also critical for addressing management problems (e.g. McLaren \& Peterson 1994, Caro \& Durant 1995). For example, is seabird predation on fish capable of limiting fisheries production (Wiens \& Scott 1975, Furness 1978, Crawford et al. 1991)?

Seabirds, as consumers of fish, have been studied to understand their role in marine ecosystems (e.g.

•E-mail:dls@grizzly.pwssc.gen.ak.us
Wiens \& Scott 1975, Hunt et al. 1981a), their physiology (e.g Nagy 1987, Birt-Friesen et al. 1989, Gabrielsen 1994), and their foraging behavior (Hoffman et al. 1981, Chilton \& Sealy 1987, Duffy 1989). These fields are often used jointly or separately to understand how seabirds and fisheries may compete for resources. Birds aggregate over and feed on concentrated food sources, such as fish schools, in the marine environment (Brown 1980, Hoffman et al. 1981, Duffy 1983, 1989), rivers, streams (Wood 1985, Ruggerone 1986, Wood 1987a, b, Kålås et al. 1993) and shallow-water estuaries (Bayer 1986, Kålâs et al. 1993). Predation by birds can limit fishery production in some circumstances (e.g. Elson 1962). Estimates of the amount of fish production taken by seabirds globally suggest that this is not usually the case. Seabirds consume between $0.8 \%$ (Sanger 1972) and 30\% (Crawford et al. 1991) of marine tertiary productivity. This range is 
quite large, and it has been suggested that the impact depends on a number of factors, including proximity to large colonies (e.g. Sanger 1972, Furness 1978, Diamond et al. 1993), whether consumption is averaged or calculated for individual prey types (e.g. Furness \& Cooper 1982, Crawford et al. 1991), whether birds are resident or migratory (Woehler 1997), and the presence of oceanographic factors such as upwelling (e.g. Haney 1986, Vermeer et al. 1987, Duffy 1989), downwelling (Hoffman et al. 1981), fronts or eddies (e.g. Haney 1986), and water clarity (e.g. Haney \& Stone 1988).

In Prince William Sound, Alaska, USA, a large commercial fishery depends on both wild and hatchery salmon production. Studies of salmon production lost to seabirds elsewhere have focused on chinook Oncorhynchus tshawytscha, sockeye $O$. nerka, and coho $O$. kisutch salmon (e.g. Ruggerone 1986, Wood 1987a, b) in North America and on Atlantic salmon Salmo salar, brown trout $S$. trutta, and Arctic char Salvelinus alpinus in Europe (Kålås et al. 1993). Estimates of losses to seabird predators in these studies ranged between 1 and $65 \%$ of hatchery and/or wild salmon production. Predation was low (1 to $10 \%$ ) when salmon were migrating downstream, because predators on the river did not follow them into saltwater (Ruggerone 1986 , Wood $1987 \mathrm{a}$, Kålås et al. 1993) Predation was higher (up to 25-65\%; Wood 1987b) when juvenile salmon were not migrating downstream. In such cases, bird predators may limit salmon production (Elson 1962). While birds are known to aggregate where salmon enter saltwater (e.g. Bayer 1986) estimates of avian predation are not generally available for mortality during this stage of the life cycle. It seems likely that predation rates upon emergence into the marine system could be high, particularly if salmon enter saltwater in a short period of time (e.g. from a large hatchery release), do not disperse immediately, and if seabirds are attracted in large numbers to concentrated fry.

In this paper we calculate the amount of hatcheryproduced salmon fry lost to avian predators as fry were releascd into the marine environment. We compared energetic model estimates with field estimates of capture rates, and examined the formation and composition of foraging flocks preying on salmon. Finally, we consider the response of seabirds to 2 ephemeral and patchy food resources (schooling herring and hatchery-reared salmon fry), and present evidence for the hypothesis that the availability of alternative prey regulates the intensity of predation by diverting seabirds to richer prey patches when they are available.

This study is part of the 'Sound Ecosystem Assessment' research program. (Cooney 1996), a component of the restoration effort following the 1989 'Exxon
Valdez' oil spill in Prince William Sound. This context has 2 important implications for this research. First, a number of other studies were ongoing in Prince William Sound in coordination with this study. We therefore have detailed background data that is unique in studies of avian consumption. For example, we used rates of growth (Willette et al. 1996) and energy contents (A. J. Paul unpubl. data) for pink salmon measured on fry samples from the same hatchery, over the same time period, and in the same location as our observations of avian predation. We used on-site boat censuses of seabirds (M. A. Bishop pers. comm.) to confirm identities of birds counted from aerial surveys, and measurements of fry size supplied by the hatcheries (Prince William Sound Aquaculture Corporation) and herring biomass supplied by Alaska Department of Fish \& Game to provide information about the prey available to birds. These details provide a rich background for our analyses. Second, the mortalities to seabirds as a direct result of the oil spill, and public sentiment against sacrificing additional birds for oil spill research precluded us from conducting lethal sampling (such as collecting birds for stomach content analysis) to confirm seabird diets. We therefore rely on field observations and the literature to confirm that salmon were included in the diets of these birds.

\section{METHODS}

Study site. We surveyed seabirds from a boat in front of the Wally Noerenberg Hatchery, located at $60^{\circ}$ $48^{\prime} \mathrm{N}, 148^{\circ} 05^{\prime} \mathrm{W}$ on Lake Bay, Esther Island, in Prince William Sound (Fig. 1), and from an airplane over other areas of the Sound (Fig. 2). The Sound is located in south central Alaska on the northern edge of the Gulf of Alaska. Prince William Sound is a large, deep (to 476 fathoms), tidal estuarine system comprised of mountainous islands, protected embayments, and glacial fjords

Wally Noerenberg Hatchery is owned and operated by the Prince William Sound Aquaculture Corporation. Between 29 April and 15 June 1995, the hatchery released into Lake Bay 169.4 million pink salmon fry at an average release weight of $0.29 \mathrm{~g}$ and 72.3 million chum salmon fry at $0.88 \mathrm{~g}$ (Prince William Sound Aquaculture Corporation unpubl data). Dense schools of fry were visible at the surface near shore throughout the entire study period following the first release. Fry were observed initially in Lake Bay, and within a day or two were also seen throughout Quillian Bay, at Esther Point, and along the west shore of Esther Island. During this same period, fry were also released at 4 other hatcheries around Prince William Sound (Fig. 2). 


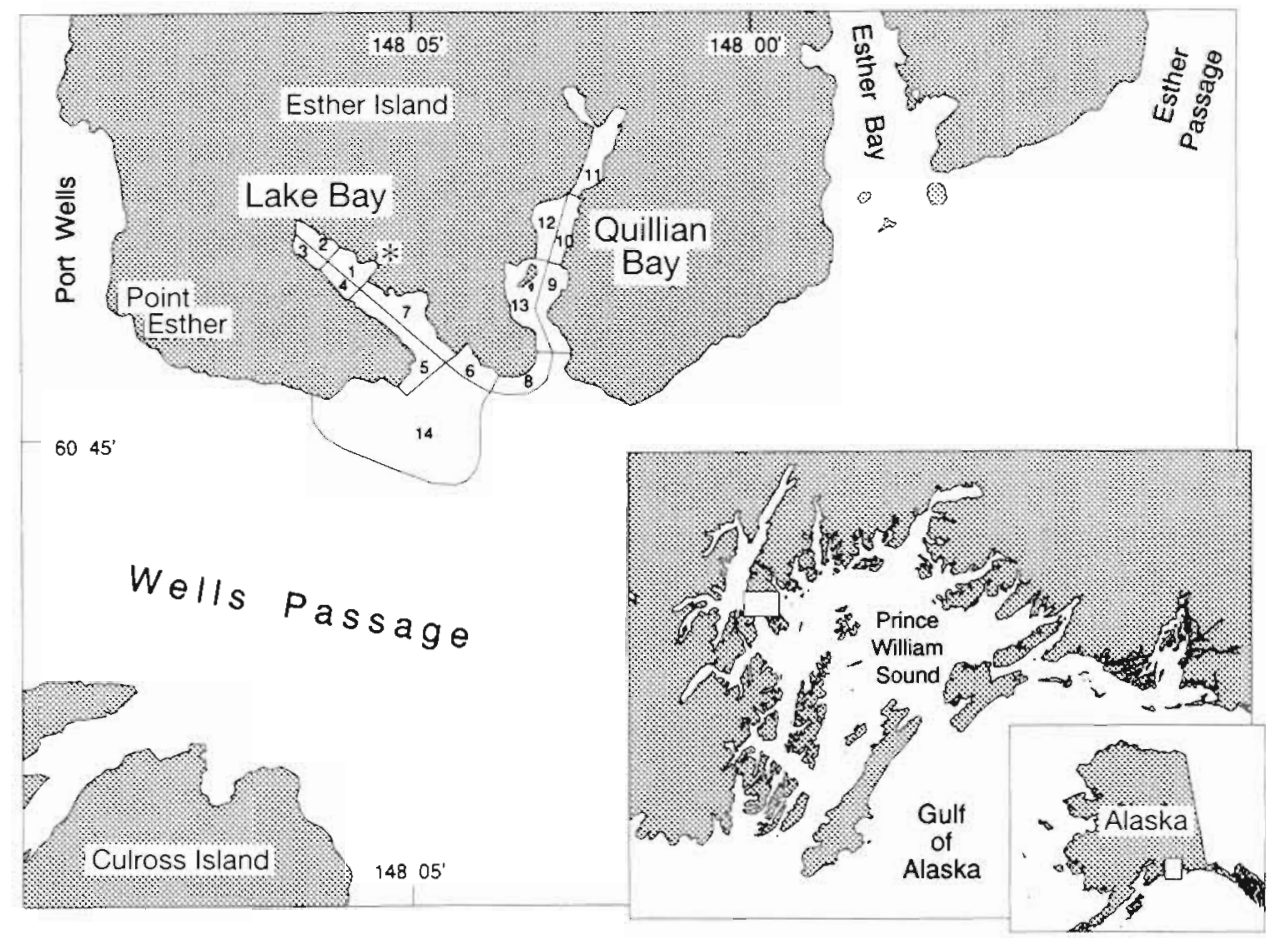

Fig. 1. Study location. Small inset indicates the location of Prince Wllliam Sound in Alaska (USA); larger inset shows Esther Island relative to Prince William Sound. (*) Wally Noerenberg Hatchery. Numbered polygons represent the count areas surveyed from a small skiff. Polygons 1 to 7 collectively form Lake Bay, 9 to 13 form Quillian Bay, and 8 and 14 form the Wells Passage count area

Bird counts at the hatchery. From 25 April to 18 May and 3 to 7 June 1995, we counted birds once or twice daily in Lake Bay, Quillian Bay, and immediately in front of these bays in Wells Passage (Fig. 1). Two observers in a small open skiff counted all birds seen over the water. We ran the boat approximately $50 \mathrm{~m}$ from shore along both sides of each bay and birds were counted on both sides of the boat from the adjacent shore out to the middle of the bay. In Area 14, which was open to Wells Passage, we counted further of fshore by running 2 transects parallel to the shore at 50 and $250 \mathrm{~m}$ from shore, providing coverage from the shore to $350 \mathrm{~m}$ out. Distances were measured using a Leitz optical rangefinder. At times, weather prohibited counting the entire study area, but we were able to survey Lake Bay even in poor weather as we were stationed at the hatchery. Birds were identified to the finest taxonomic resolution discernable in the field (to species for almost all birds). Due to the relatively straight and steep shorelines of these bays, we feel that very few birds on or near the water were missed during these surveys.

The effect of tide height and flow, sea surface state, precipitation, wind speed and direction, and time of the survey on bird counts were examined using ANOVAs. We tested for effects of these variables on each of the 7 piscivores, total birds, and total piscivores; and hence used a conservative p-value of 0.01 For these analyses, we used data from Lake Bay only.
This provided the largest sample size $(\mathrm{n}=29)$ over a broad range of weather, tides, and time of day. In calculating salmon consumption (see below), however, our analyses included only days when all 14 count areas were surveyed $(n=21)$ because fry were eaten throughout this entire area and weather did not effect bird numbers (see 'Results').

Consumption of fry. Only the most abundant piscivorous seabirds (Table 1) were included in estimates of consumption of fry. To determine which birds consumed salmon fry, we relied on observations of behavior in the field as well as published accounts of diet. Black-legged kittiwakes, Arctic terns and Bonaparte's gulls are plunge-diving foragers (Table 1), which plunge from the air into the water only to depths at or just below the surface (Hoffman et al. 1981). These species were classified as piscivores because they were observed feeding on fry. Mew gulls were considered piscivores because they were observed in mixed-species foraging flocks where salmon fry were abundant. Marbled murrelets and both mergansers are pursuit divers (Table 1; observed in this study), which remain submerged for sustained periods and may emerge some distance from where they entered the water (Haney \& Stone 1988). We could not directly observe predation on salmon fry by pursuit divers; however, they were observed in mixed-species foraging flocks near concentrations of fry and are known to consume juvenile 

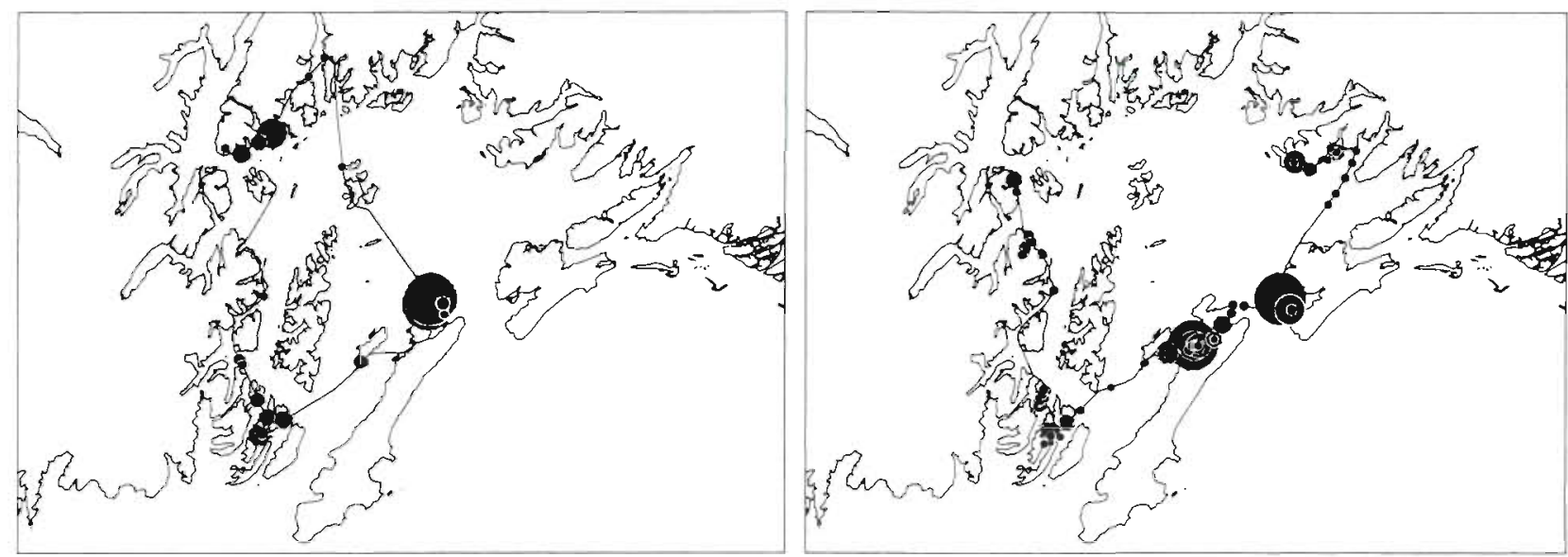

a. 24-Apr-95


d. $16-$ May- $\overline{95}$
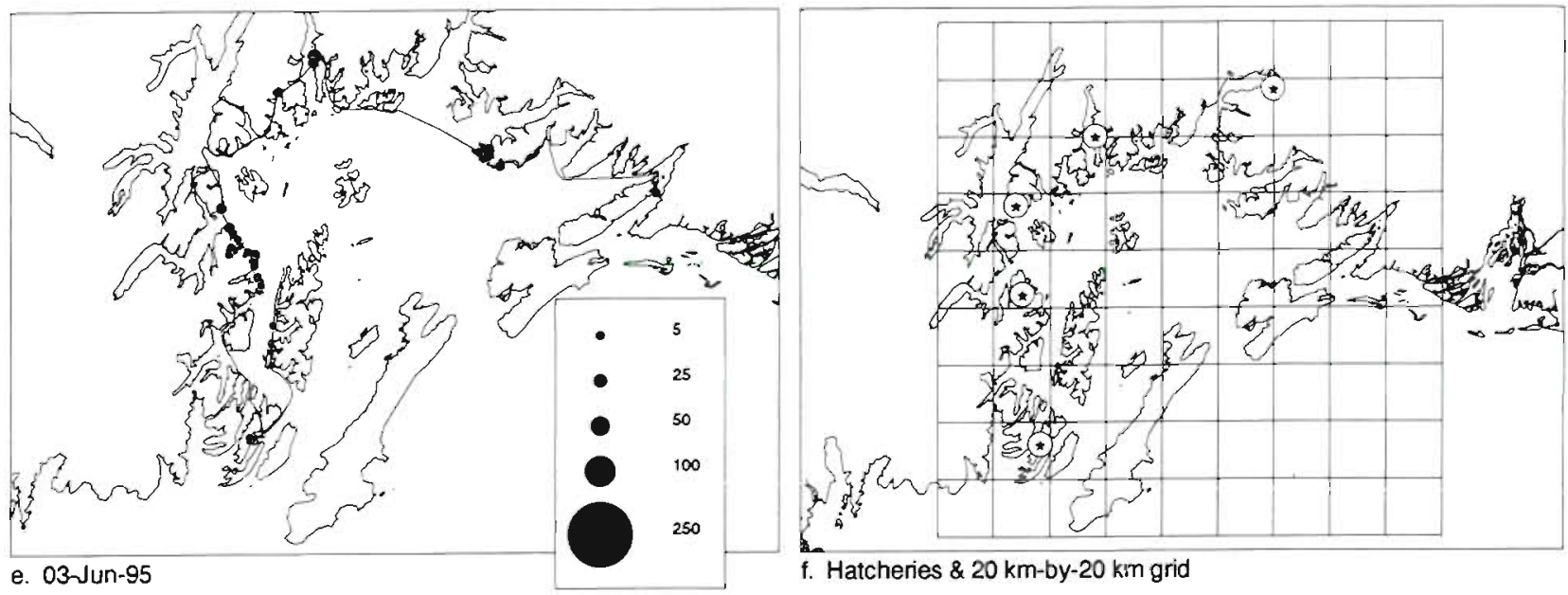

Fig. 2. Flight paths and locations of birds visible from the air during aerial surveys (a-e: only flocks of $\geq 5$ birds are shown) and the $20 \times 20 \mathrm{~km}$ grid cells used for analyses of this data (f: circled stars indicate hatchery locations)

salmon (Table 1). We therefore considered them to be piscivores for the purposes of this study.

In contrast, glaucous-winged gulls, Barrow's goldeneyes, and Harlequin ducks were not seen plungediving or diving in mixed-species foraging flocks dur- ing this study. Fish is not known to be a regular part of the diet of either duck (Bellrose 1976), although both are known to consume fish eggs (M. A. Bishop pers comm.). Although Glaucous-winged Gulls are known to eat fish. (Hoffman et al. 1981, Sanger 1987), none 
Table 1 The 10 most common species counted in Lake and Quillian Bays (Prince William Sound, Alaska, USA). 'Diet' for purposes of calculating consumption of salmon fry by seabirds: P, piscivorous; $N$, non-piscivorous. See 'Methods' for further explanation. Total count: numbers of birds (and proportion of total count) for each of the 10 most common species. These 10 species of birds comprised $93 \%$ of all birds in the hatchery area during the study period. See Fig. 5 for daily variation in numbers of kittiwakes, murrelets, and total piscivores

\begin{tabular}{|c|c|c|c|c|c|}
\hline Common name & Species & Diet & Source & $\operatorname{Mass}(\mathrm{kg})^{\mathrm{b}}$ & Total count \\
\hline All species & & & & & $7333(1.00)$ \\
\hline Black-legged kittiwake & Rissa tridactyla & $\mathrm{P}$ & $7,9,12$ & $0.383^{c}$ & $1957(0.27)$ \\
\hline Marbled murrelet & Brachyramphus marmoratus & $\mathrm{P}$ & $5,7,11$ & $0.205^{\mathrm{d}}$ & $1851(0.25)$ \\
\hline Glaucous-winged gull & Larus glaucescens & $\mathrm{N}$ & See text & & $793(0.11)$ \\
\hline Arctic tern & Sterna paradisaea & $\mathrm{p}$ & $1,2,4,7,12$ & $0.101^{\circ}$ & $499(0.07)$ \\
\hline Red-breasted merganser & Mergus serrator & $\mathrm{P}$ & 3,8 & $0.794^{\prime}$ & $413(0.06)$ \\
\hline Common merganser & M. merganser & $P$ & 10 & $1.134^{\mathrm{f}}$ & $355(0.05)$ \\
\hline Barrow's goldeneye & Bucephala islandica & $\mathrm{N}$ & 3 & & $319(0.04)$ \\
\hline Harlequin duck & Histrionicus histrionicus & $\mathrm{N}$ & 3 & & $265(0.04)$ \\
\hline Bonaparte's gull & L. philadelphia & $\mathrm{P}$ & 4,12 & $0.205^{9}$ & $211(0.03)$ \\
\hline Mew gull & L. canus & $\mathrm{P}$ & 6 & $0.430^{\mathrm{h}}$ & $178(0.02)$ \\
\hline \multicolumn{6}{|c|}{  } \\
\hline
\end{tabular}

were seen in this study attempting to pursue fry or feeding on the water. We therefore consider these species non-piscivores for purposes of calculating consumption of salmon fry by birds.

Behavioral data: Focal-animal sampling (Altmann 1974) was conducted on the 3 abundant plunge-divers for which all successful captures of fry could be recorded: black-legged kittiwakes, Bonaparte's gulls, and Arctic terns. We did not see enough mew gulls to conduct focal-animal samples. Individuals were observed during feeding bouts in mixed-species flocks. After sampling, we noted whether or not salmon fry were visible near the surface of the water where seabirds had been foraging For focal-animal samples, an individual active bird in the flock was chosen and followed with binoculars for 3 to $5 \mathrm{~min}$. Sampling ended after $5 \mathrm{~min}$ or when the bird flew out of view. Samples of less than 3 min were discarded. Samples were not adjusted for the time the bird spent in non-foraging activities (e.g. resting). A prey capture was recorded only if we saw the bird with a fish in its beak after a plunge-dive. Capture rates were calculated for each of the 3 species as number of prey captures divided by the sample duration and averaged over all samples. Estimates of the time per day spent in active feeding were made from the reported behavior of radio-tagged kittiwakes in Prince William Sound during the chickrearing period in July (Irons 1992). We are aware of no other literature on the daily active foraging times of terns or gulls, and so used our calculation for kittiwakes as the foraging time for the other plunge-divers (Arctic terns, Bonaparte's gulls). Daily per capita consumption was estimated for each species as the capture rate times the daily time spent actively feeding.

Energetic models: Energetic modeling provides an alternative way to calculate daily consumption of fry by seabirds, assuming that the birds meet some fixed portion of their daily energetic demands by feeding on salmon fry within the study area. We used 3 different mass-metabolic rate regression equations available in

Table 2. Parameters for the regression $y=m x+b$, where $y$ is the log of field metabolic rate and $x$ is the mass of the bird. Nagy (1987) reports mass as grams rather than kılograms, and we retain his usage in this table. Birt-Friesen et al. (1989) reported regressions for cold-water seabirds and cold-water seabirds using flapping flight

\begin{tabular}{|lccccc|}
\hline Source & Intercept (SE) & Slope (SE) & Mass range & Unit & $\mathrm{n}$ \\
\hline Nagy (1987) & $0.904(0.187)$ & $0.704(0.061)$ & $420-9440$ & $\mathrm{~g}$ & 15 \\
$\begin{array}{l}\text { Birt-Friesen et al. (1989) } \\
\quad \text { Cold-water, all seabirds }\end{array}$ & $3.13(0.03)$ & $0.646(0.040)$ & $0.043-13.0$ & $\mathrm{~kg}$ & 16 \\
$\quad$ Cold-water, flapping flight & $3.24(0.05)$ & $0.727(0.039)$ & $0.083-3.210$ & $\mathrm{~kg}$ & 8 \\
\hline
\end{tabular}


the literature (Table 2) to calculate field metabolic rates (FMRs) for the common piscivores in our study area. By dividing FMR by the energy content of fry, we estimated the number of fry required to meet a bird's energetic demand. The models we chose used doubly labeled water measurements of FMRs to calculate a relationship between FMR and body mass. The seabird assemblages used to develop these models varied considerably, and provided a range of predicted FMRs (Fig. 3). Developing a model for the seabird assemblage in this study area was outside the scope of this paper; however, we consider the effects of the modelled assemblages in the 'Discussion'.

To estimate the number of fry required to meet seabird energetic demand, we calculated the energy content of the average fry in front of the hatchery for each day of the study period as:

$$
E_{a, t}=\frac{\sum_{r} W_{t, r} E_{n} N_{t, r}}{\sum_{r} N_{t, r}}
$$

where

$$
\begin{aligned}
& W_{t, r}=W_{0, r}(1+G)^{t} \\
& N_{t, r}=N_{0, r}(1-m)^{\prime}
\end{aligned}
$$

$E_{a, t}$ is the energy content of the average fry at $t$ days post-release and $E_{n}$ is the energy content of $1 \mathrm{~g}$ of salmon fry. $W_{t, r}$ is the average weight of fry from a given release $r$ at time $t$ starting from an average weight of $W_{0}$ measured for pen $r$ and assuming a growth rate of $G$. $N_{t, r}$ is the number of fry remaining from a given release at $t$ days post-release starting with $N_{0}$ fry released on Day 0 and assuming a movement rate of $m$.
Average release weights $\left(W_{0, r}\right)$ and numbers released $\left(N_{0, r}\right)$ for each pen of pink and chum salmon fry were provided by the Prince William Sound Aquaculture Corporation, and growth rate of pink salmon fry $(G)$ was provided by $M$. Willette (Willette et al. 1996. Alaska Department of Fish \& Game pers. comm.). Growth was measured from recaptured coded-wire tagged fry released from Wally Noerenberg Hatchery in late April or early May 1995. Fry were recaptured during June and growth was calculated as $G=4.2 \%$ body weight per day during this period. Pink and chum fry were found in mixed schools in front of the hatchery and were likely feeding on the same prey. We therefore assumed that the measured growth rate of pink salmon fry applied to chum salmon fry as well. We calculated the average weight of fry in each cohort $\left(W_{t, r}\right)$, starting with the measured release weight on the day of release $\left(W_{0, r}\right)$, for each day until 15 June 1995. The mass of the average fry in front of the hatchery changed depending on fiy growth, release of new fry and loss of fry to movement or predation. To estimate the mass of the average fry on a given day, we assumed that fry from each release cohort left the area at a fixed rate per day $(m)$. The average mass of fry remaining was then calculated from known release weights, dates, and growth rates. We used 2 different estimates of fry departure rates: a low movement rate of $m=2.5 \%$ departure per day and a high rate of $m=50 \%$ departure per day (Fig. 4).

The per-gram energy content of pink salmon fry $\left(E_{n}\right)$ captured on 31 May at Esther Point in Wells Passage (Fig 1) was measured using bomb calorimetry ( $\bar{x}=$ $3.21 \mathrm{~kJ} \mathrm{~g}^{-1}$ wet weight, $\mathrm{n}=62$; A. J. Paul unpubl. data). We recognize that the energetic content may differ between pink and chum fry and may change through-

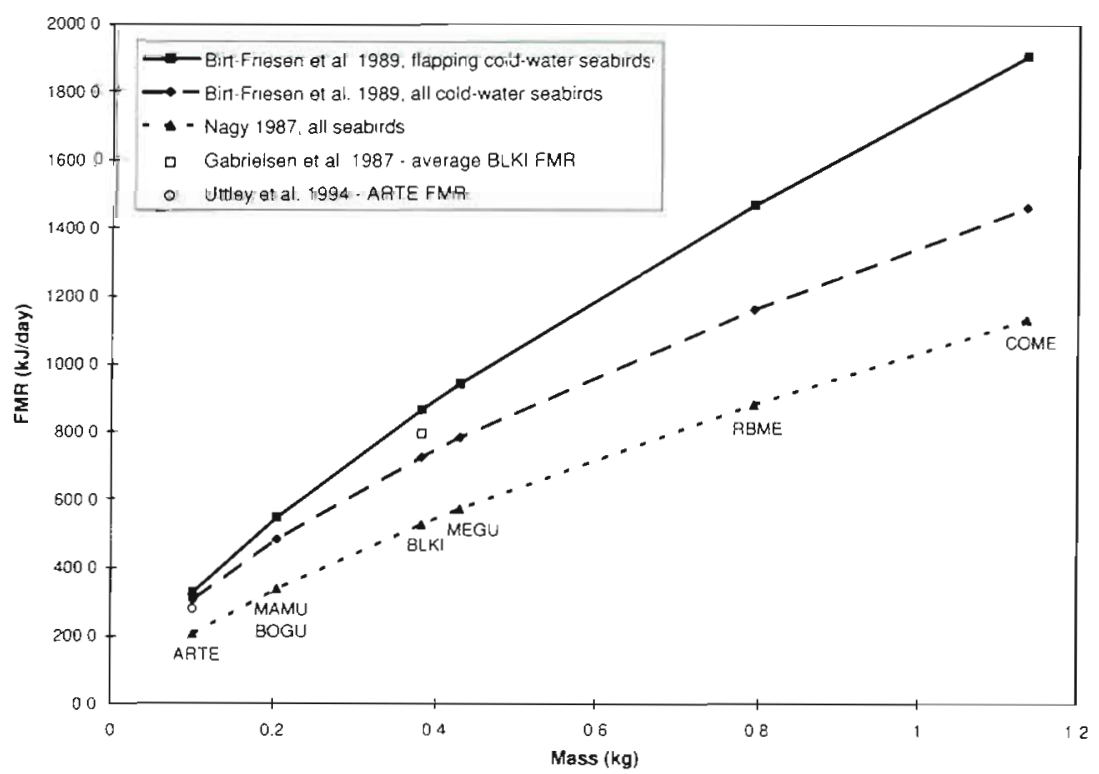

Fig. 3. Comparison of some published energetic models for seabirds. Mass regression equations and parameters are given in Table 3. Measured field metabolic rates (FMR) for black-legged kittwakes (FMR equals the average of on nest and off nest measurments; Gabrielsen et al. 1987) and Arctic terns (Uttley et al. 1994) are also plotted for comparison to predicted values. See text for a discussion of differences between the models. Species are plotted based on the body masses in Table 1: Arctic tern (ARTE), marbled murrelet (MAMU), Bonaparte's gull (BOGU), black-legged kittiwake (BLKI), mew gull (MEGU), redbreasted merganser (RBME), and common merganser (COME) 
Fig. 4. Numbers of fry remaining in front of the hatchery under 2 estimates of movement rates. We assumed that either $2.5 \%$ (low movement) or $50 \%$ (high movement) of fry in the area leave each day. The high movement scenario was equivalent to assuming an average movement rate of $2 \mathrm{~km} \mathrm{~d}^{-1}$ Note that while this parameter had a large effect on the number of fry remaining in the area (left axis, boxes), the effect on the energy content of the average fry (right axis, no boxes) was much smaller

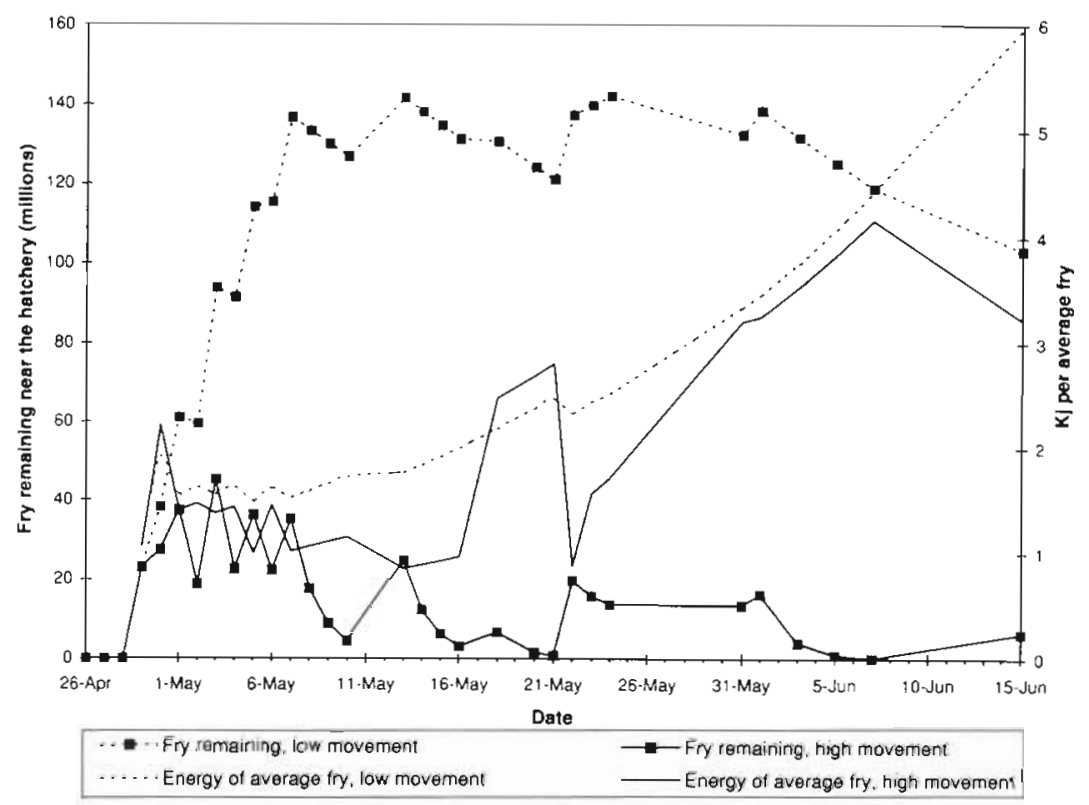

out the season. However, to simplify our calculations, we assumed this was a reasonable approximation of salmon energy content for the purposes of this paper, and used this value as the energy content of pink and chum salmon throughout the study period. For each cohort of fry, the energy content per fry was calculated for each day as the weight of the fry times $3.21 \mathrm{~kJ} \mathrm{~g}^{-1}$. Finally, we calculated the energy content of the average fry in front of the hatchery $\left(E_{a, t}\right)$ as the energy content for each cohort of fry releases weighted by the abundance of fry from that cohort $\left(N_{t}\right)$ assuming low or high movement rates (Fig. 4).

Seabird daily per capita consumption rates were calculated as the predicted FMRs for each species divided by $E_{a, t}$. Per capita consumption was multiplied by the number of piscivores present to estimate total consumption of fry each day. These were summed to calculate cumulative consumption over the study period. We assumed birds ate sufficient fry to meet their energy demands. No corrections were made for weight gain or loss by the birds, seasonal changes in energy demand. less than $100 \%$ salmon in the birds' diets or less than $100 \%$ assimilation efficiencies. These simplifications were necessary because we could not make the necessary measurements in this study and there were insufficient data in the literature. However, we consider the effects of relaxing these assumptions in the 'Discussion'.

Aerial surveys. Birds were also censused during 5 aerial surveys (24 April, 1, 8, 16 May, and 3 June 1995) using high-resolution video photography. The survey route consisted of a fixed portion of the western Prince William Sound shoreline that was included in every flight, and a variable portion that on each flight cov- ered different parts of the eastern and central Sound shorelines (Fig. 2). The fixed portion of the survey path overflew salmon hatcheries at Esther Island (Wally Noerenberg Hatchery), Main Bay (Main Bay Hatchery), and Evans Island (Armin F. Koernig Hatchery). The survey plane was equipped with a global positioning system (GPS) linked high-resolution video camera. Surveys were flown at an altitude of $180 \mathrm{~m}$ (600 feet). Single white birds can readily be seen and counted from the videotape filmed at this altitude. During each survey, 2 observers also recorded all birds visible on either side of the plane out to a visual angle of about $30^{\circ}$ The videotapes include a transect $200 \mathrm{~m}$ wide directly under the plane and observers counted to either side of the plane to about $500 \mathrm{~m}$, but could not see directly under the plane. Birds were counted from video during playback and their positions were mapped. It was not possible to identify birds on videotape to species, nor to reliably see dark birds. The tapes were therefore analyzed as a sample of white birds, largely gulls.

GPS-recorded flight paths and the locations of bird flocks were entered into a geographic information system using Arc/Info 6.1 (Environmental Systems Research Institute Inc, 1982-95, Redlands, CA, USA). Information on the distribution of fish was obtained from Prince William Sound Aquaculture Corporation (release dates, numbers, and sizes of salmon fry reared at each hatchery) and the Alaska Department of Fish \& Game (estimated tons of herring gathered for spawning at beaches and linear miles of herring spawn deposited). A $20 \times 20 \mathrm{~km}$ grid was overlaid on the study area (Fig. 2f); and the linear miles of survey flight, total number of birds, total tons of herring seen at beaches 
over the $7 \mathrm{~d}$ preceding the flight, cumulative hatchery fry released, and cumulative kilometers of herring spawn deposited along the shoreline were calculated for each grid cell. ANOVAs were used to evaluate the correspondence of bird numbers per linear kilometer of survey to each of the other variables in each surveyed grid cell.

\section{RESULTS}

\section{Numbers of birds}

Sixty-five species of birds were observed during boat counts in this study. However, 10 species collectively made up $93 \%$ of all counts (Table 1 ). Seven of the 10 most common species were piscivores, totaling $80 \%$ of individuals of these 10 species. Of the 7 piscivorous species, $52 \%$ were kittiwakes or murrelets. Overall, piscivorous birds increased in the count area during the period of fry releases (Fig. 5). Black-legged kittiwakes arrived and dispersed quickly, apparently in response to each individual release, although this relationship was not significant (Kruskal-Wallis ANOVA: $\mathrm{d} f=2, T=4.6, p=0.098$ ). Marbled murrelet numbers began to increase about $1 \mathrm{wk}$ following the start of releases and continued to increase throughout the release period. A notable exception to this trend was the decrease in marbled murrelet numbers beginning 11 May, which corresponded to a $10 \mathrm{~d}$ period $(8$ to 17 May) in which there was only 1 fry release (13 May). Murrelet numbers began to rise again following the 13 May release (Fig. 5). Groups of Bonaparte's gulls and Arctic terns fed in the area for several days and then moved on. Red-breasted mergansers increased gradualiy through mid-May and declined by early June. Common mergansers were abundant initially, but declined beginning in early May. Mew gulls were present in small numbers throughout.

Arctic tern counts were higher during heavy rain than during light or no rain (ANOVA: $F=5.65, p=$ $0.004)$. Otherwise we found no significant effects of any of the environmental variables (tide height and flow, sea surface state, wind speed and direction, precipitation, time of the survey) on any measure of bird numbers, including total birds counted, total piscivores, or numbers of any of the individual piscivorous species. Counts of Arctic terns and marbled murrelets were lower during surveys conducted later in the day, possibly reflecting a bias toward foraging more in the morning and using other areas following satiation. The significance of these relationships were marginal given that over 40 tests were included in this analysis (ANOVAs: terns, $F=7.56, \mathrm{p}=0.011$; murrelets, $F=$ $4.08, p=0.055$ ). Estimates of fry consumed are unlikely to be biased by this relationship because only 4 of the 21 surveys that included both Lake and Quillian Bays were conducted after midday, and 2 of these were before fry release and therefore did not influence estimates of consumption.

\section{Observed feeding rates}

Black-legged kittiwakes, Arctic terns, and Bonaparte's gulls were observed in mixed-species foraging flocks where schools of salmon fry were visible near the surface. In no case did we fail to find a school of fry

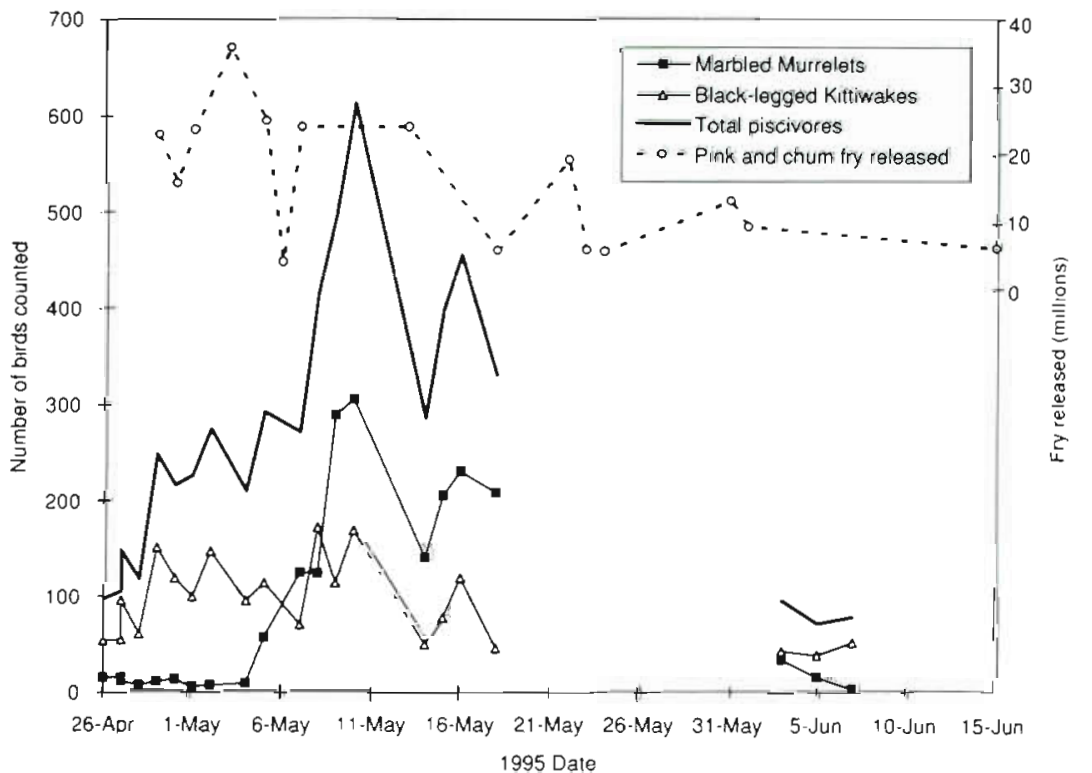

Fig. 5. Numbers of marbled murrelets, black-legged kittiwakes, and total piscivores counted in the study area. Salmon fry release dates and numbers are shown for comparison. Note that zero on the right axis has been raised to visually separate the fry release line from the bird counts. Piscivores increased in the area in response to fry releases, and decreased when intervals between releases were longer 
Table 3. Observed feeding rates of 3 piscivores. $n$ is the number of focal animal samples. Note that hours per day spent foraging was calculated as the time per foraging trip spent in search behavior (e.g. localized circling, plunging; 60 to $80 \mathrm{~min} \mathrm{trip}^{-1}$; Irons 1992) times the number of foraging trips per day. We assumed that birds made 2 foraging trips per day (Irons 1992) and spent $70 \mathrm{~min}^{-1} \mathrm{pip}^{-1}$ actively searching and feeding. This estimate was used for all species

\begin{tabular}{|lccc|}
\hline Species & Sample time $(\mathrm{n})$ & Fry h$^{-1}(\mathrm{SE})$ & Foraging $\left(\mathrm{h} \mathrm{d}^{-1}\right)$ \\
\hline Black-legged kittiwake & $0: 42(9)$ & $98.2(71.3)$ & 2.3 \\
Bonaparte's guil & $0: 20(4)$ & $66.0(23.0)$ & 2.3 \\
Arctic tern & $0.31(7)$ & $65.2(37.8)$ & 2.3 \\
\hline
\end{tabular}

low fry movement and cold-water flapping seabirds, high fry movement respectively).

During 1995, 241.7 million pink and chum fry were released into Lake Bay. Our estimates of mortality from fish-eating birds represent between 1.1 and $2.4 \%$ of the total release. Our assumptions about the movement rates of fry account for $36 \%$ of this range in estimates: higher movement rates resulted in less growth before fry left the area, and hence lower mass per fry on average. Therefore more fry were required under the high movement rate scenario to meet seabird energetic where birds were feeding during a focal-animal sample ( $\mathrm{n}=8$ foraging flocks). These 3 species foraged on salmon by plunge-diving (although birds also appeared to forage by picking at items in the surface layer, we observed no captures of small fish by surfaceseizing). Focal-animal birds caught only a single fry in each observed capture, and were not under water long enough to consume fry without being observed. Feeding rates ranged from 65 to 98 ( \pm 23.0 to $71.3 \mathrm{SE}$ ) fry per hour per bird (Table 3 ). Multiplied by foraging time per day (Table 3), this yielded estimates of daily per capita consumption from 150 fry for Bonaparte's gulls to 230 fry for black-legged kittiwakes. (We have no error estimate for foraging time per day, and hence were unable to calculate standard error for daily per capita consumption. At a minimum, however, it will be 2.3 times the hourly error.)

These rates may be compared to rates derived from the energetic models (Table 2), provided that we can estimate the energy content of the fry being consumed. We multiplied a mass of $0.53 \mathrm{~g} \mathrm{fry}^{-1}$ (the mass of the average fry in front of the hatchery on May 10) by $3.21 \mathrm{~kJ} \mathrm{~g}^{-1}$ to convert $\mathrm{kJ} \mathrm{d} \mathrm{d}^{-1}$ required by the energetic models to fry $d^{-1}$. The observed capture rates were lower than rates estimated from the energetic models of Birt-Friesen et al. (1989). They were lower than estimates from Nagy (1987) for kittiwakes and Bonaparte's gulls, but slightly higher for Arctic terns (Fig. 6).

\section{Cumulative mortality to fry}

Cumulative mortality to fry reflected differences in the energetics models (Fig. 7). Using Nagy's (1987) model, we arrived at a total mortality from birds of 2.7 to 3.6 million fry (for low and high fry movement respectively). The models of Birt-Friesen et al. (1989) gave estimates of 3.8 to 5.9 million fry (all cold-water seabirds, accounted for the remaining $64 \%$ of the range (Fig. 7).

\section{Distribution of birds relative to fish}

Five aerial surveys were flown during which bird aggregations were counted and mapped (Fig. 2a-e). The best multivariate model (squared multiple $\mathrm{R}=$ 0.442 ) predicting total birds per kilometer of flight in each grid cell contained the variables of tons of schooling herring, presence of hatcheries, and date (ANOVA, herring: $F=7.79, \mathrm{p}=0.007$; hatcheries: $F=22.16, \mathrm{p}<$ 0.001 , date: $F=6.70, \mathrm{p}=0.013$ ). Both herring schools and herring spawn were present in the survey area from mid-April to the first week in May, overlapping the period of early fry release; but herring had dispersed before the week that maximum piscivore counts were obtained at the hatchery (Fig. 5). Total demands. Differences between the energetic models



Fig. 6. Comparison of per capita consumption of fry per day for 3 plunge-diving seabirds based on observed feeding rates and energetic models 


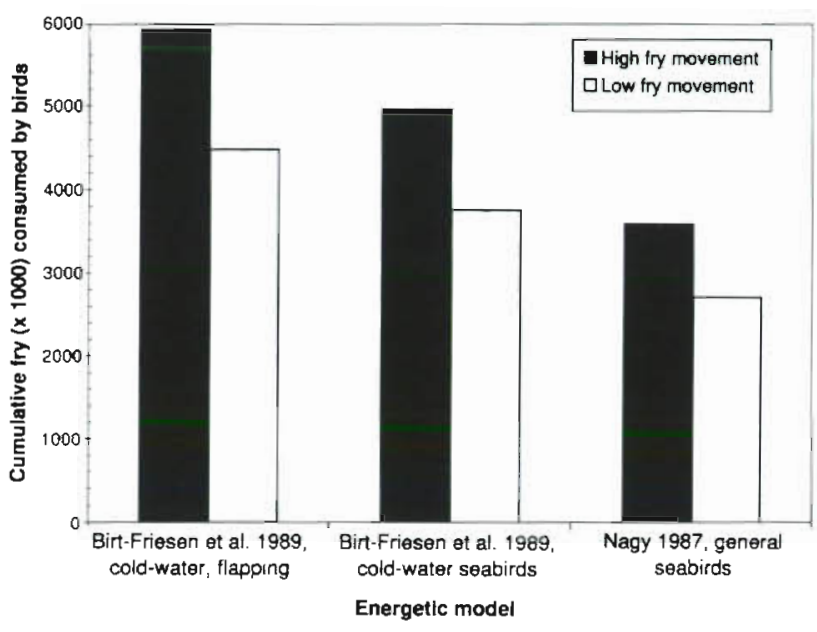

Fig. 7. Cumulative consumption of pink and chum fry by 7 species of seabirds from 29 April 1995, the first day of fry release, to 7 June 1995, the last day that birds were counted. Consumption was based on the 3 energetic models listed along the $x$-axis, and calculated assuming both high and low fry movement rates. See text for details

birds per kilometer of flight was higher in grid cells that contained larger amounts of schooling herring; and there was no significant relationship between cumulative kilometers of herring spawn in a grid cell and bird numbers. The cumulative number of fry released and the presence of a hatchery in a grid cell were both predictors of total birds per kilometer (fry release: regression, $T=3.56, \mathrm{p}=0.029$ when the effect of schooling herring was included). However, these variables are confounded, and hatchery presence alone was the better predictor. A tendency for birds to accumulate as more fry were released may have been masked by the decline in seabird numbers from April through June, which was reflected in a negative correlation with the date and which also occurred in bird counts at the hatchery (Fig. 5).

\section{DISCUSSION}

We provided a range of estimates of the amount of salmon hatchery production consumed by seabirds in the period shortly after fry were introduced into the marine environment. Seabirds consumed 1.1 to $2.4 \%$ of fry released. In arriving at this range, we compared estimates based on 3 models of seabird energetics (Nagy 1987, Birt-Friesen et al. 1989) to field measurements of prey capture rates. We found that measured capture rates were lower than the most reasonable estimate from energetics. Finally, we examined the distribution of seabird flocks relative to 2 prey types: salmon fry released from hatcheries and herring aggregated along the shoreline prior to spawning
Seabirds were more likely to be found near either prey source than in areas without these prey. Taken together, these results indicate that salmon fry just entering the marine environment were susceptible to avian predation, but that their vulnerability to predation may be buffered by other attractive food patches within the foraging range of seabirds.

No strong responses of bird counts were found to time of survey, tidal, or weather variables. Although these are known to affect bird behavior (e.g. Bayer 1986), their effects in this study were probably minimized by several factors: we conducted almost all surveys in the morning, the intertidal is very steep and hence its extent does not vary greatly between low and high tide, tidal currents in the area are weak, and steep mountains on either side shelter the bays from strong winds. Our surveys could not measure night feeding or turnover of individual birds at the site, factors that would increase the numbers of fry consumed

Numbers of piscivorous seabirds increased during the period of fry release (Fig 5) and declined afterwards, an aggregative response to prey (e.g. Piatt 1990). However, species responded differently: kittiwake counts increased for short periods only, while murrelet numbers increased gradually over all periods of frequent release (Fig. 5). Hoffman et al. (1981) identified roles that species have in foraging-flock formation and dispersal in Alaska: catalysts (e.g. kittiwakes) initiate flock formation; divers (e.g. murrelets) exploit food sources to which they are attracted by more conspicuous foragers and may facilitate foraging of all species by concentrating prey near the surface (Chilton \& Sealy 1987). Our finding suggests a component of this system not previously remarked upon in studies of seabird flock dynamics: clivers accumulated at a favorable foraging patch over a period of weeks, whereas catalysts did not. This pattern may reflect the flight efficiencies of these birds. Divers may show greater site fidelity to food patches than do catalyst species if divers are less efficient fliers due to specialization of the wings for diving.

The models we chose to estimate energetic demands relied on doubly labeled water measurements of field metabolic rates of seabirds. Other models of seabird energetic demand were available, but these estimated basal metabolic rates (Ellis 1984, Diamond et al. 1993, Gabrielsen 1994) or produced results similar to models we included (e.g. Koteja 1991 and Birt-Friesen et al.'s 1989 cold-water seabird equations were equivalent). To avoid converting between basal and field metabolic rates, we restricted our analyses to models that were based on FMRs. Nonetheless, more than half of the difference between our low and high estimates of total fry consumed was attributed to differences between the energetic models (Fig. 7) 
Differences between the seabird assemblages used to develop the FMR allometric equations explain why the models vary. Nagy's (1987) model included warmwater species, which typically have lower metabolic rates than arctic and subarctic birds (Ellis 1984). Nagy (1987) included only $53 \%$ cold-water species (with $33 \%$ warm-water birds and $13 \%$ non-designated, following Birt-Friesen et al. 1989, $\mathrm{n}=15$ samples from 10 species) while Birt-Friesen et al. (1989) presented models restricted to cold-water seabirds. Birt-Friesen et al. (1989) provided a further division of the cold-water seabird assemblage to include only flapping seabirds in cold-water ( $\mathrm{n}=8$ samples from 8 species), which predicted the highest FMRs. The general cold-water seabird model of Birt-Friesen et al. (1989) includes data from a variety of species not typical of our study area (e.g. penguins). The 7 common piscivore species aggregated in front of Wally Noerenberg Hatchery during this study were all flapping seabirds. Although the cold-water model for flapping seabirds encompasses a small range of body sizes (Montevecchi et al. 1992), it includes species that span a greater range in body size than the 7 piscivores in our study. This model is therefore most appropriate for our purposes.

Consumption estimates from the behavioral data were generally lower than those of the energetics models (Fig. 6). Measurements of FMRs were taken during courtship through post-brooding due to the ease of recapturing a bird at a nest or colony (Nagy 1987, Birt-Friesen et al. 1989, Koteja 1991). Although our early counts in April to early May likely included many birds not engaged in energetically expensive breeding activities, the study did overlap the breeding season for all of the piscivores (Isleib \& Kessel 1973, Bellrose 1976, Hunt et al. 1981b. Ehrlich et al. 1988, Kuletz 1995). Therefore, while FMR equations may not be representative of the activities of birds during the first part of our study, neither did we feel justified (based on breeding activity) in assuming that the models were too high for our purposes.

However, several other factors may explain the discrepancy. First, we applied a literature value for blacklegged kittiwakes active foraging time to Arctic terns and Bonaparte's gulls because of a lack of published values for the latter species. At the consumption rates we observed, kittiwakes would require from 3.4 to $5.6 \mathrm{~h}$ of foraging per day to meet energetic demands estimated by the models; Bonaparte's gulls would require 3.0 to $4.8 \mathrm{~h}$ while Arctic terns would need 1.8 to $2.9 \mathrm{~h}$. Second, we did not correct for the inclusion of items other than salmon fry in the diet. We saw birds that appeared to capture and consume a prey item without having fish visible in their beaks. These birds may have been consuming smaller prey such as amphipods. Birds may also have been selectively prey- ing on larger fry in a school (but see Kålås et al. 1993 for a conflicting report). To the extent that birds ate other prey or larger prey, fewer fry would be required to meet their energetic demands. Third, we assumed assimilation efficiencies (AEs) of $100 \%$ to simplify our calculations and because of a lack of published values for these species on salmon. If we apply an $A E$ of $77.2 \%$ (average for birds eating fish; Castro et al. 1989), our estimated consumption from energetic models would increase by $29.5 \%$. With the exception of assimilation efficiencies, we were unable to estimate the size of these biases. While it is also possible that these birds do not have to meet the energetic demands estimated by the models, measured FMRs for both black-legged kittiwakes (Gabrielsen et al. 1987) and Arctic terns (Uttley et al. 1994) fell towards the higher FMR estimates (Fig 3), suggesting that estimates based on models of energetic demand for cold-water flapping seabirds were reasonable.

On 5 aerial surveys over western Prince William Sound (Fig. 2), gulls were associated with spawning herring and with hatchery sites. Gulls were aggregated both over beaches where herring had spawned, and in grid cells with schooling herring. In some surveys, we observed birds circling over schooling fish: and gull numbers in the aerial surveys were significantly correlated only with the recent presence of schools of herring aggregated to spawn, not with amount of spawn deposited. The correlation of 'white' bird aggregations with the presence of both salmon fry and herring indicates that concentrations of prey fish have an important influence on the distribution of birds along the shoreline during this time of the year. Birds feed on these fish, as well as scavenge or steal food from other predators attracted to the same prey (Hoffman et al. 1981). Hatchery managers anecdotally report large variation in bird numbers that are attracted to releases each year. This may be explained if birds aggregate at the best feeding sites: when available, these are the spawning migrations of herring, sandlance, or other fish. When the spawning of these prey fish does not coincide with. fry release or outmigration, then more birds may be attracted to feed on salmon fry at hatcheries and streams. This pattern is suggested by the fact that bird numbers at the hatchery increased only gradually for the first 10 to $15 \mathrm{~d}$ of fry release while schools of spawning herring were recorded in the study area, but peaked following the first week in May (Fig. 5) when herring had dispersed or left the area. Additional data is required to test this idea, but losses of salmon fry to seabirds would likely be greater in years when many more birds were attracted to release sites. Gull abundances in the aerial surveys declined as the season progressed; and counts recorded at Wally Noerenberg Hatchery also declined 




by early June. Gulls therefore appear to leave the open shorelines of the Sound or become less visible towards the end of May. At this time, these birds were likely to be incubating eggs (Isleib \& Kessel 1973, Bellrose 1976, Hunt et al. 1981b, Ehrlich et al. 1988, Kuletz et al. 1995) and may spend less time foraging and more time at colonies, or shift their activities further up into inlets and fjords, thereby escaping detection during these surveys.

We estimated a cumulative mortality to fry of 1.1 to $2.4 \%$ of pink and chum salmon releases. This estimate is not unexpected given the physical structure of the habitat and the behavior of the fish. In 5 studies of avian predation on salmon, mortality rates were high when predation occurred in constrained environments such as streams and when salmon were resident rather than migratory (Table 4: merganser predation limited salmon productivity, Huntsman $1941 ; 24$ to $65 \%$, Wood $1987 \mathrm{~b}$ ). In contrast, when salmon were seaward migrants rather than residents, stream mortality was lower (Table $4: 2$ to $10 \%$, Ruggerone 1986, Wood 1987 a, Kålås et al. 1993). However, our models predicted greater loss of fry with high movement than with low movement. These scenarios differed in the size of the average fry that remained in front of the hatchery because, with high movement, fry left the area before they grew large. Predators at the hatchery thus either ate many small fry (high movement) or fewer larger fry (low movement) to meet their energetic demands, and predation rates consequently were higher when prey were more mobile. However, if we consider a case where low and high movement fry were both present, predators should focus on the low-movement, larger fry over the smaller fry that quickly disperse.

Our study also differed from the 5 mentioned above because salmon fry were not confined by a stream channel: fry entered a deep bay and migrated toward more open water (Fig. 1). Constrained habitat may make fry vulnerable to predators (e.g. dolly varden in stream channels had more fry per predator in their stomachs than did dolly varden at the mouths of streams; Kirkwood 1962). A few studies have noted predators aggregating near salmon fry as they enter the marine environment (Table 4; e.g. seabirds, Bayer 1986; fish. Thorsteinson 1962, Bakshtansky 1964. Dobrynina et al. 1989, Nagasawa \& Kaeriyama 1995), but none have estimated cumula- 
tive mortality rates. More regional studies have estimated losses of fish (or tertiary production) to seabirds, generally reporting losses of 10 to $30 \%$ (Table 4 ), a level intermediate to those of migrant versus resident juvenile salmon (Huntsman 1941, Ruggerone 1986, Wood 1987a, b, Kålås et al. 1993).

in previous studies, estimates of fish losses to birds were lower $(0.6$ to $30 \%)$ in marine systems over large areas and when prey were migratory rather than resident in the area. The large range in these estimates may be attributed to differences between prey species; for example, off southern Africa seabirds took $31 \%$ of anchovy production but only 1 to $6 \%$ of other prey (Crawford et al. 1991). Conversely, estimates were higher ( 10 to $60 \%$ of available prey) in freshwater systems (rivers and lakes) where fish were physically constrained in a small body of water, where prey were resident rather than migratory (thereby extending the period over which predation can occur), and near seabird colonies where predator populations were highest (e.g. Sanger 1972, Furness 1978, Diamond et al. 1993).

Acknowledgements. We thank the personnel of the Prince William Sound Aquaculture Corporation (notably Howard Ferrin, the 1995 staff of the Wally Noerenberg Hatchery, and volunteer birders who collected data at the hatchery). Scott Wilbur, and the Sound Ecosystem Assessment research program for assistance with all aspects of this research. D.S. thanks Tania Vincent for her tolerance, care, and intellectual contributions throughout. A. J. Paul, Mark Willette, and Rob Suryan generously shared preliminary results of their own work. This research was supported by the 'Exxon Valdez' Oil Spill Trustee Council and the Valdez Fisheries District Association. However, the findings and conclusions presented by the authors are their own and do not necessarily reflect the views or position of the Trustee Council. We thank reviewers of the 'Exxon Valdez' Oil Spill Restoration Office for comments on the design of this research, and Mark Willette and 2 anonymous reviewers for comments on the manuscript. This project was part of the Sound Ecosystem Assessment Program of the Prince William Sound Science Center, the Alaska Department of Fish and Game, Prince William Sound Aquaculture Corporation, and the University of Alaska, Fairbanks.

\section{LITERATURE CITED}

Altmann J (1974) Observational study of behavior - sampling methods. Behaviour 49:227-264

Bakshtansky EL (1964) The impact of the environmental factors on survival of the Far Eastern young salmon during the acclimatization of the latter in the northwestern part of the USSR. ICNAF Spec Publ 6:477-479

Bayer RD (1986) Seabirds near an Oregon estuarine salmon hatchery in 1982 and during the 1983 El Niño. Fish Bull US $84(2): 279-286$

Bellrose FC (1976) Ducks, geese \& swans of North America. Stackpole Books, Harrisburg

Birt-Friesen VI, Montevecchi WA, Cairns DK, Macko SA (1989) Activity-specific metabolic rates of free-living northern gannets and other seabirds. Ecology 70(2):357-367
Braune BM, Gaskin DE (1982) Feeding methods and diving rates of migrating larids off Deer lsland, New Brunswick. Can J Zool 60:2190-2197

Brown RGB (1980) Seabirds as marine animals. In: Burger J, Olla BL, Winn HE (eds) Behavior of marine animals: current perspectives in research. Plenum Press, New York, p 1-39

Caro TM, Durant SM (1995) The importance of behavioral ecology for conservation biology: examples from Serengeti carnivores. In: Sinclair ARE, Arcese P (eds) Serengeti II: dynamics, management, and conservation of an ecosystem. University of Chicago Press, Chicago, p 451-472

Carter HR, Sealy SG (1986) Year-round use of coastal lakes by Marbled Murrelets. Condor 88:473-477

Castro G, Stoyan N, Myers JP (1989) Assimilation efficiency in birds: a function of taxon or food type? Comp Biochem Physiol 92A(3):271-278

Chilton G, Sealy SG (1987) Species roles in mixed-species feeding flocks of seabirds. J Field Ornithol 58(4): $456-463$

Cooney RT (1996) Sound Ecosystem Assessment (SEA) - an integrated science plan for the restoration of injured species in Prince William Sound, Alaska. Exxon Valdez Oil Spill Restoration Project Annual Report (Restoration Project 95320). Alaska Department of Fish and Game, Anchorage (Available from the Oil Spill Information Center, 645 G Street, Anchorage, AK 99501, USA)

Crawford RJM, Ryan PG, Williams AJ (1991) Seabird consumption and production in the Benguela and Western Agulhas ecosystems. S Afr J Mar Sci 11:357-375

Diamond AW, Gaston AJ, Brown RGB (1993) A model of the energy demands of the seabirds of eastern and Arctic Canada. Canadian Wildlife Service, Ottawa, Ontario

Dobrynina MV, Gorshkov SA, Kinas NM (1989) Effect of density of juvenile pink salmon, Oncorhynchus gorbuscha, on their vulnerability to predators in the Utka River (Kamchatka). J Ichthyol 29(1):148-155

Duffy DC (1983) The foraging ecology of Peruvian seabirds. Auk 100:800-810

Duffy DC (1989) Seabird foraging aggregations: a comparison of two southern upwellings. Colon Waterbirds 12(2): $164-175$

Ehrlich PR, Dobkin DS, Wheye D (1988) The birder's handbook: a field guide to the natural history of North American birds. Simon \& Schuster Inc, New York

Ellis HI (1984) Energetics of free-ranging seabirds. In: Whittow GC, Rahn H (eds) Seabird energetics. Plenum Press, New York, p 203-234

Elson PF (1962) Predator-prey relationships between fisheating birds and Atlantic salmon. Bull Fish Res Bd Can 133

Furness RW (1978) Energy requirements of seabird communities: a bioenergetics model. J Anim Ecol 47:39-53

Furness RW, Cooper J (1982) Interactions between breeding seabird and pelagic fish populations in the Southern Benguela region. Mar Ecol Prog Ser 8:243-250

Gabrielsen GW (1994) Energy expenditure in arctic seabirds. PhD dissertation. University of Tromsø. Tromso

Gabrielsen GW, Mehlum F, Nagy KA. (1987) Daily energy expenditure and energy utilization of free-ranging Blacklegged kittiwakes. Condor 89:126-132

Haney JC (1986) Seabird affinities for Gulf Stream frontal eddies: responses of mobile marine consumers to episodic upwelling. J Mar Res 44:361-384

Haney JC, Stone A.E (1988) Seabird foraging tactics and water clarity: are plunge divers really in the clear? Mar Ecol Prog Ser 49:1-9

Hatch SA, Sanger CA (1992) Puffins as samplers of juvenile 
pollock and other forage fish in the Gulf of Alaska. Mar Ecol 80:1-14

Hoffman W, Heinemann D. Wiens JA (1981) The ecology of seabird feeding flocks in Alaska. Auk 98:437-456

Hugie DM, Dill LM (1994) Fish and game: a game theoretic approach to habitat selection by predators and prey. J Fish Biol 45(Suppl A):151-169

Hunt GL Jr, Burgeson B, Sanger GA (1981a) Feeding ecology of seabirds of the Eastern Bering Sea. In: Hood DW, Calder JA (eds) The Eastern Bering Sea Shelf: oceanography and resources, Vol 2. University of Washington Press, Seattle, $p$ 629-647

Hunt GL Jr, Eppley Z, Drury WH (1981b) Breding distribution and reproductive biology of marine birds in the Eastern Bering Sea. In: Hood DW, Calder JA (cds) The Eastern. Bering Sea Shelf: oceanography and resources, Vol 2. University of Washington Press, Seattle, p 649-687

Huntsman AG (1941) Cyclical abundance and birds versus salmon. J Fish Res Bd Can 5(3):227-235

Irons DB (1992) Aspects of foraging behavior and reproductive biology of the Black-legged Kittiwake. PhD dissertation, University of California, Irvine

Isleib ME, Kessel B (1973) Birds of the North Gulf Coast Prince William Sound region, Alaska. University of Alaska Press, Fairbanks

Kảlås JA, Heggberget TG, Bjørn PA, Reitan O (1993) Feeding behaviour and diet of goosanders (Mergus merganser) in relation to salmonid seaward migration. Aquat Living Resour 6:31-38

Kirkwood JB (1962) Inshore marine and freshwater life history phases of the pink salmon (Oncorhynchus gorbuscha) and chum salmon (O. keta) in Prince William Sound, AK. $\mathrm{PhD}$ dissertation, University of Louisville

Korpimaki E. Krebs CJ (1996) Predation and population cycles of small mammals. B1oSci 46(10):754-764

Koteja P (1991) On the relation between basal and field metabolic rates in birds and mammals. Funct Ecol 5:56-64

Kuletz KJ, Marks DK, Flint D, Burns R, Prestash L (1995) Marbled Murrelet foraging patterns in Prince William Sound, Alaska. Exxon Valdez Oil Spill Restoration Project Final Report, US Fish and Wildlife Service, Anchorage (Available from the Oil Spill Information Center, 645 G Street, Anchorage, A.K 99501, USA)

McLaren BE, Prterson RO (1994) Wolves, moose, and tree rings on Isle Rovale. Science 266:1555-1558

Mehlum F, Gabrielsen GW (1995) Energy expenditure and. food consumption by seabird populations in the Barents Sea region. In: Skjoldal HR, Hopkins C, Erikstad KE, Lcinaas HP (eds) Ecology of fjords and coastal waters. Elserifir Science, Amsterdam, p 457-470

Montevecchi WA, Birt-Friesen VL, Cairns DK (1992) Reproductive energetics and prey harvest of Leach's Stormpetrels in the northwest Atlantic. Ecology 73(3):823-832

Mossman AS (1959) Notes on gull and tern food habits in Alaska. In: Johnson AW (ed) Proceedings of the 10th Alaskan Science Conference. Alaska Division, AAAS, Juneau, Alaska, p 86-87

Nagasawa K, Kaeriyama M (1995) Predation by fishes and seabirds on juvenile chum salmon (Oncorhynchus keta) in coastal waters of Japan: a review. Sci Rep Hokkaido Salmon Hatch 49:41-53

Nagy KA (1987) Field metabolic rate and food requirement scaling in mammals and birds. Ecol Monogr 57(2):111-128

Nilsson SG, Nilsson IN (1976) Numbers, food consumption,

This article was submitted to the editor and fish predation by burds in Lake Möckeln, southern Sweden. Ornis Scand 7:61-70

Palmer RS (1976) Handbook of North American birds. Yale University Press, New York

Piatt JF (1990) The aggregative response of common murres and Atlantic puffins to schools of capelin. Avi Biol 14:36-51

Rochette R, Himmelman JH (1996) Does vulnerability influence trade-offs made by whelks between predation risk and feeding opportunities? Anim Behav 52(4):783-794

Ruggerone GT (1986) Consumption of migrating juvenile salmonids by gulls foraging below a Columbia river dam. Trans Am Fish Soc 115(5):736-742

Sanger GA (1972) Preliminary standing stock and bıomass estimates of seabirds in the subarctic Pacific region In: Takenouti AY (ed) Biological oceanography of the northern north Pacific ocean. Idemitsu Shoten. Tokyo, p 589-611

Sanger GA (1987) Trophic levels and trophic relationships of seabirds in the Gulf of Alaska. In: Croxall JP (ed) Seabirds: feeding ecology and role in marine ecosystems. Cambridge Univ Press, New York, p 229-257

Terres JK (1980) The Audubon Society encyclopedia of North American birds. Alfred A Knopf, New York

Thorsteinson FV (1962) Herring predation on pink salmon fry in a southeastern Alaska estuary. Trans Am Fish Soc 91(3): $321-323$

Uttley J, Tatner P. Monaghan P (1994) Measuring the dally energy expenditure of free-living Arctic terns (Sterna paradisaecil. Auk 111(2):453-459

Vermeer K, Szabo I. Greisman P (1987) The relationship between plankton-feeding Bonaparte's and Mew gulls and tidal upwelling at Active Pass, British Columbia. J Plankton Res 9(3):483-501

Vincent TLS, Scheel D, Brown JS, Vincent TL (1996) Tradeoffs and coexistence in consumer-resource models: it all depends on what and where you eat. Am Nat 148(6): $1038-1058$

Volterra $V$ (1926) Fluctuations in the abundance of a species considered mathematically. Nature 118:558-560

Wiens JA, Scott JM (1975) Model estimation of energy flow in Oregon coastal seabird populations. Condor 77:439-452

Willette M, Carpenter G, Saddler P. Powell M (1996) Sound ecosystem assessment: salmon growth and mortality. Exxon Valdez Oil Spill Restoration Project Annual Report (Restoration Project 95320A), Alaska Department of Fish and Game, Anchorage (Available from the Oil Spill Information Center, 645 G Street, Anchorage, AK 99501, USA)

Williams RB (1947) Notes on the Arctic tern in Alexander Archipelago, southeastern Alaska. Auk 64:143-144

Woehler EJ (1997) Seabird abundance, biomass and prey consumption within Prydz Bay, Antarctica, 1980/19811992/1993. Polar Biol 16:(in press)

Wood CC (1985) Aggregative response of Common mergansers (Mergus merganser): predicting flock size and abundance on Vancouver Island streams. Can J Fish Aquat Sci 42:1259-1271

Wood CC (1987a) Predation of juvenile Pacific salmon by the Common merganser (Mergus merganser) on eastern Vancouver Island I: predation during the seaward migration. Can J Fish Aquat Sci 44:941-949

Wood CC (1987b) Predation of juvenile Pacific salmon by the Common merganser (Mergus merganser) on eastern Vancouver Island II: predation of stream resident juvenile salmon by merganser broods. Can J Fish Aquat Sci 44 : $7.50-957$

Manuscnpt first received: May 20, 1996

Revised version accepted: February 10, 1997 